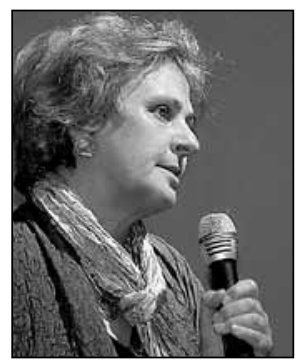

\title{
PATRICIA FEENEY
}

Patricia Feeney is the Executive Director of Rights and Accountability in Development, a British NGO that conducts research into corporate accountability, human rights and the extractive industries. Mrs Feeney is a research affiliate of the University of Oxford where she teaches post-graduate students. She is a founder of OECD Watch, a network set up to monitor the implementation of the OECD Guidelines for Multinational Enterprises. She is the author of numerous reports and articles including Accountable Aid (Oxfam Publications, Oxford 1998).

Email: tricia.feeney@raid-uk.org

\section{ABSTRACT}

Over the past 40 years the United Nations has made various attempts to develop global standards to hold companies accountable for their involvement in human rights abuses. This article traces the growing awareness of business-related human rights abuses and the limitations of the traditional State-centric approach to regulating corporations in the era of globalisation. It reflects on the reasons for the demise of the Draft UN Norms on the Responsibilities of Transnational Corporations and considers the strengths and weaknesses of 'the Protect, Remedy and Respect Framework' adopted by the Human Rights Council in 2008. The article concludes with a warning that unless the demands for global standards and an effective remedy for those affected by corporate misconduct are addressed, pressure for change is only liable to intensify.

Original in English.

Submitted in October 2009. Accepted in November 2009.

\section{KEYWORDS}

Business and human rights - UN norms - Corporate accountability 


\section{BUSINESS AND HUMAN RIGHTS:THE STRUGGLE FOR ACCOUNTABILITY IN THE UN AND THE FUTURE DIRECTION OF THE ADVOCACY AGENDA}

Patricia Feeney

\section{Introduction}

This article traces the various attempts over the past 40 years by the United Nations (UN) to develop global standards to hold companies accountable for their involvement in human rights abuses. It argues that the business and human rights agenda came into its own due to (i) the growing awareness of the potential human rights obligations of non-state actors; (ii) the increasing recognition of social and economic rights; and (iii) campaigns outside of the UN system against the destructive nature of large development projects, which ushered in new ways of holding financial institutions to account for environmental and social harms. The article examines the different UN initiatives that have been proposed to monitor and regulate business, along with the backlash these efforts prompted from business groups and governments, keen to protect their perceived economic interests. The draft Norms on the Responsibilities of Transnational Corporations and Other Business Enterprises with Regard to Human Rights (UNITED NATIONS, 1983 - hereinafter, Norms) was an attempt to deal with the inadequacy of the traditional State-centric approach to regulating corporate behaviour in the era of globalisation (UNITED NATIONS, 2006, para. 11). The article goes on to cast a critical, but constructive, look at the mandate of the UN Secretary-General's Special Representative on Business and Human Rights (SRSG). It concludes with an assessment of the status of the current business and human rights debate and offers a perspective on the future direction of the corporate accountability agenda. 


\section{Early developments: from the 1970 s to the 1990 s}

Concerns about the impact of powerful commercial interests on the lives of people and their environment are nothing new. The struggle to curb and restrain economic actors has a long pedigree. In the early 1970s, the revelations about wide scale unethical and illegal activities by multinational companies prompted calls for international regulation of corporations. Two of the best known incidents were the involvement of ITT and other US companies in the 1973 Chilean coup and the bribes paid by Lockheed to Japanese officials to obtain military contracts (SALZMAN, 2005; UNITED STATES OF AMERICA, 1975). In the 1970s and 1980s, activism aiming at business actors often took the form of boycotts, particularly of companies and banks that provided economic support to the Apartheid regime in South Africa. Companies that supplied military equipment to regimes engaged in systemic human rights abuses were also targeted during this time (HANLON, 1990).

In response to the growing public unease about the role of companies in relation to human rights, the United Nations became a natural focus for efforts to strengthen the accountability of business actors in the 1970s. The UN Commission on Transnational Corporations was established in 1973, for example, to investigate the effects of transnational corporations (TNCs) and strengthen the negotiating capacity of countries in which they operate. (JERBI, 2009) The resulting draft UN Code of Conduct on TNCs (UNITED NATIONS, 1983) was the first attempt to provide global social and environmental guidelines for transnational corporations ${ }^{1}$. This UN Code of Conduct process, however, faced stiff resistance from powerful governments in the North, where many TNCs had their headquarters. Despite support from many governments in the global South, the UN Code of Conduct project was first sidelined and then over time derailed ${ }^{2}$.

Rich countries, fearing the emergence of a global UN initiative regulating business, then turned to the Organization of Economic Cooperation and Development (OECD) for a solution. In 1975, the Committee for International Investments and Multinational Enterprises was established to investigate the possibility of codes of conduct for TNCs (SALZMAN, 2005). The OECD wanted first and foremost to protect international investors from discrimination and expropriation by host country governments. In 1976, then, the OECD Guidelines for Multinational Enterprises came into being as part of "The Declaration and Decisions on International Investment and Multinational Enterprises" (SALZMAN, 2005). The Guidelines, while they did incorporate some labour rights, had no explicit reference to other human rights. They were widely perceived as a token concession to civil society concerns about the power of multinationals and the instrument, which underwent various revisions, remained little used for two decades (SALZMAN, 2005).

In 1977, the International Labour Organisation (ILO) adopted the Tripartite Declaration of Principles Concerning Multinational Enterprises and Social Policy (INTERNATIONAL LABOUR OFFICE, 1977), which calls for corporations to respect the Universal Declaration of Human Rights and the corresponding 
international human rights covenants. Though not legally binding, and focused specifically on workers' rights, this Declaration did establish a mechanism through which civil society groups, in cooperation with trade unions, can bring claims concerning business abuse ${ }^{3}$.

Throughout the 1980s, civil society campaigns exposed the harmful role played by the World Bank in supporting large-scale development projects in many low-income countries which generated environmental destruction and human rights harm. Campaigns against mega projects like the Narmada Dam in India and Polonoroeste in Brazil exposed the multiple failures of the World Bank to lift people out of poverty, to defend the rights of indigenous peoples and to protect the environment (RICH, 1995). Structural adjustment programmes and reduced aid flows during this period also worked to pry open the economies of developing countries to foreign investment. NGOs in turn began to develop increasingly sophisticated critiques of the macroeconomic policies of the IMF and World Bank. In response to such pressure, the World Bank's Inspection Panel was later created, which offered a new, if limited, method of holding powerful international economic actors to account (FEENEY, 1998). It also offered a template which might be replicated in relation to the private sector.

Nonetheless, throughout the 1980s and 1990s, the size and power of TNCs grew exponentially (UNITED NATIONS, 2007b), and suspicion grew that the interest of global business was being promoted in various inter-governmental bodies over and above the rights of everyday citizens. Public awareness about sweatshop labour conditions prompted picketing outside some retail stores. In 1995, human rights activist Ken Saro-Wiwa and eight others were executed following an unfair trial brought in retaliation for their protests against Shell Oil in Nigeria. The late 1990s witnessed widespread protests, epitomized in 1999 in Seattle by a march of 100,000 people demonstrating against the World Trade Organization (WTO), perceived by activists as a body set up to increase the mobility and power of business globally. This was all against a backd rop of a surge in domestic litigation, especially in courts in the United States and Europe, against companies accused of directly committing human rights violations or being complicit in human rights violations committed by host States (INTERNATIONAL COUNCIL ON HUMAN RIGHTS POLICY, 2002).

These struggles to exact accountability from national-level courts, international organizations and from companies themselves was coupled with a series of UN Summits and conferences in the 1990s which strengthened ties between NGOs and social movements and influenced the environment for corporate accountability moving forward. The most important were the Earth Summit in Rio de Janeiro (1992), the World Conference on Human Rights (Vienna, 1993) and the Women's Summit (Beijing, 2006). In these conferences, the divisions between human rights, environment and development activists began to gradually break down as new alliances were formed.

Other walls were also pulled down in this period. The World Human Rights Conference in Vienna for its part acknowledged that all human rights are universal, indivisible, interdependent and inter-related. Before Vienna, civil and political rights 
were privileged by most human rights organizations in the North, while economic, social and cultural rights were neglected and marginal. Vienna helped to redress the balance. The human rights community was challenged to 'to move beyond old certainties' and to reconsider the assumption that recognition of economic, social and cultural rights would inevitably undermine the status of civil and political rights (ALSTON, 1994). In this context in Vienna, NGOs and indigenous peoples spoke out on 'hazardous industrialisation' and 'harmful development projects' and challenged the negative impact of several early free trade agreements. (ALSTON, 1994) There were also calls in Vienna for a reform of the international financial institutions and for an end to structural adjustment policies which eroded the capacity of the State in much of the developing world, with 'particularly severe and discriminatory impacts on women' (CLAPHAM, 2006). So, while the UN summits and conferences throughout this period did not have a particular focus on corporate accountability, they helped promote a new sensibility about development and human rights. The movement for women's rights and gender equity also played an increasingly prominent role in these debates and helped promote the concept of the responsibility of private actors for human rights violations ${ }^{4}$.

It was against the background of increased mobilization and growing discontent, that three initiatives emerged, each with their own standards and modalities. These were the UN Global Compact, the OECD Guidelines for Multinational Enterprises and the Norms.

In 1999, the UN Secretary-General Kofi Annan launched the UN Global Compact, described as a voluntary learning initiative aiming to align business operations with ten principles in the area of human rights, labour, environment and anti-corruption. But, like many other corporate social responsibility initiatives, the Global Compact lacked a means of enforcing its principles, and thus was considered by many amongst civil society as insufficient on its own to end the startling levels of impunity enjoyed by TNCs (TEITELBAUM, 2007).

By the end of the 1990s, campaigns exposing human rights-related problems in the garment and textile sector and the extractive industries spawned a dizzying number of private company and industry-wide codes. This led to renewed calls for global standards to define a common benchmark for business conduct in relation to human rights. In 1998, NGOs and unions helped defeat the plans of the member governments of the OECD for a Multilateral Agreement on Investment (MAI), which they perceived as an attempt to promote the interests of foreign investors over and above the development needs and priorities of low-income countries (SALZMAN, 2005). Chastened by the MAI debacle and fearful of a rising tide of anti-globalization protests, these governments embarked on a major revision of the OECD Guidelines for Multinational Enterprises in which NGOs were for the first time allowed to participate. The new text, unveiled in June 2000, included an explicit reference to the Universal Declaration on Human Rights. The implementation procedures were revamped to enable NGOs and others to bring complaints about corporate misconduct to the attention of home governments, including for actions that occurred outside of OECD territories. The struggle for accountability seemed to be gaining ground. 


\section{The fight for universal human rights standards: UN Norms on the Responsibilities of Transnational Corporations and Other Business Enterprises with Regard to Human Rights}

This environment of growing demands for meaningful curbs on abusive practices of businesses also prompted efforts at the UN Sub-Commission on the Promotion and Protection of Human Rights an advisory expert body to the UN Commission on Human Rights (the latter is now known as the Human Rights Council) to develop a draft international instrument based on human rights law to strengthen corporate accountability. In 2003, after four years of discussions and consultations, the Sub-Commission approved the 'Norms on the Responsibilities of Transnational Corporations and Other Business Enterprises with Regard to Human Rights' (Norms) (UNITED NATIONS, 2003).

At its heart, the Norms embodied and articulated four general principles: that while States were the primary duty-holders, business actors also have responsibilities under international human rights law; these responsibilities apply universally and cover a broad range of rights; governments need to take action to protect people from abuses by companies; and the transnational nature of the problem requires that there be monitoring of company behaviour and enforcement mechanisms beyond national boundaries to ensure that companies comply with the Norms and relevant national and international law when operating outside their borders.

In general, civil society strongly endorsed the Norms and hoped that the core ideas would eventually form the basis for the development of binding international law (ESCR-Net, 2005). The reaction of business, however, was largely hostile. The Norms quickly became a lightning rod for counter-lobbying, spearheaded by various business associations. Along with business, many governments were also deeply uncomfortable with the document. Several substantive criticisms were advanced by opponents of the Norms. The Norms failed to distinguish clearly between the human rights obligations of States and the responsibilities of companies, some critics asserted. Others argued that international human rights law could only be directly applicable to States, thereby rejecting the notion that businesses have human rights duties. The Commission for its part expressed the view that, while the Norms contained "useful elements and ideas", as a draft the proposal it had no legal standing (UNITED NATIONS, 2004). To move the process forward, the Office of the United Nations High Commissioner for Human Rights (OHCHR) was requested to consult widely in the elaboration of a report examining the scope and legal status of existing initiatives and standards, including the Norms (UNITED NATIONS, 2004). By this time, however, the debate had already become polarized.

In 2005, despite strong lobbying and various favourable submissions including the report by the OHCHR which encouraged a review of the Norms, the Commission failed to explicitly mention the Norms and called on the Secretary General to appoint a Special Representative on the issue of business and human rights (UNITED NATIONS, 2005a, para. 2). The Commission's swift neglect 
of the Norms effectually consigned them to the same fate as the Draft Code of Conduct for TNCs. The lack of political will to adopt a truly global instrument on business and human rights was indeed a setback for the corporate accountability movement. But, the Norms did play an important role in shaping the debate as one leading commentator noted:

Whether or not the Norms develop..., the stage has been set for the development of a normative framework that sets out the meaning of human rights obligations of corporations. Any such exercise will have to not only revisit the terrain covered by the Norms, but also consider how the international legal order has developed beyond an exclusive concern with state actors (CLAPHAM, 2006, p. 237).

So, despite controversies over the Norms' precise content and legal standing, the initiative served an important purpose towards the increasingly shared recognition that companies have responsibilities to all human rights everywhere, that national governments must act to protect people from abuses by companies, and that extraterritorial or global monitoring and enforcement mechanisms are needed. In this sense, the development and promotion of the UN Norms laid the ground-work for future steps to prevent human rights violations involving business and hold those responsible to account.

\section{The Special Representative to the Secretary General on Business and Human Rights}

Professor John Ruggie, Kofi Annan's former chief adviser for strategic planning, was appointed the Special Representative on Business and Human Rights (SRSG) in $2005^{5}$. He had previously been involved in the creation of the UN Global Compact and the drafting of the Millennium Declaration. Unlike the mandates of other UN Special Procedures, which often require country visits and engagement with directly-affected people, the work of the SRSG was to be limited to a "desk-study" ${ }^{6}$. The mandate, despite civil society lobbying, did not then require the SRSG to examine specific situations of business-related abuse (UNITED NATIONS, 2005a). Thus, from the outset, the mandate marginalised the individuals and communities directly affected by business abuse, effectively denying them a voice in the debate. In his first report, the new SRSG did, however, note the problems inherent in globalisation and the need for some means of reducing the likelihood of corporate misconduct.

In a move that seemed to be calculated to appeal to business groups, but one which further alienated many NGOs, the SRSG swiftly closed down further discussion of the Norms, insisting that they were so deeply flawed that no part could be salvaged (UNITED NATIONS, 2006, para. 69). Yet, as commentators noted at the time, this wholesale rejection of all aspects of the Norms made little sense because parts of the document simply restated international legal principles already applicable to business with regard to human rights. (KINLEY; CHAMBERS, 2006). Nevertheless, the SRSG made clear that he regarded the 
UN Norms project as dead, basing his assessment on the two criticisms that the Norms by implication purported to invent a new avenue of international law directly applicable to corporations, and that the Norms ill-defined the respective obligations of States and corporations (UNITED NATIONS, 2006).

The SRSG's 2006 interim report concluded nevertheless that the need remained for a common, international set of ultimately enforceable standards articulating the human rights responsibilities of business. Leading NGOs in a written response to the Interim Report stated that the Norms, irrespective of their perceived shortcomings, had "potential and ought to have been supported as a viable first step in the establishment of an international legal framework through which companies can be held accountable for human rights abuses they inflict, or in which they are complicit". The NGOs stressed the need of developing international human rights standards for business that would move beyond existing frameworks and the status quo, and avoid the pitfall of reaching agreements that merely reflect the "lowest common denominator". The NGOs were also critical of what they perceived to be the SRSG's failure to appreciate the inadequacy of voluntary standards and mechanisms. (ESCR-NET, 2006) The report's key pitfall, one could say, was that it seemed to be more concerned with "human rights challenges" facing business rather than the human rights abuses faced by victims.

While the restrictive mandate given to the SRSG seemed to be a step backwards by many NGOs rather than progress toward corporate accountability, others saw the approach taken by the SRSG as essential in order to achieve support from the business community and overcome government reluctance (JERBI, 2009). The balance between the interests of business and the needs of affected people was slightly restored in the 2007 report which was described as a "mapping exercise" to illustrate existing international standards, instruments and treaty body guidance in the field of corporate responsibility and accountability (UNITED NATIONS, 2007a). The report recognized that the expansion of markets and the transnational reach of corporations had not been matched by an expansion in protection for individuals and communities suffering businessrelated human rights abuse:

Clearly, a more fundamental institutional misalignment is present: between the scope and impact of economic forces and actors, on the one hand, and the capacity of societies to manage their adverse consequences, on the other. This misalignment creates the permissive environment within which blameworthy acts by corporations may occur without adequate sanctioning or reparation. For the sake of the victims of abuse, and to sustain globalization as a positive force, this must be fixed (UNITED NATIONS, 2007a, para. 3).

The report also noted the inability or unwillingness of many States to offer protection against corporate abuse. But again, with the exception of the OECD Guidelines for Multinational Enterprises, the SRSG offered few criticisms of voluntary or multi-stakeholder initiatives, such as the Voluntary Principles on Security and Human Rights, which he seemed to endorse and encourage (UNITED 
NATIONS, 2007a, para.18). Many amongst civil society further called on the SRSG to turn his focus to the perspective of victims, consult more widely with them, and appropriately reflect the results of meetings with affected groups. Groups also urged the SRSG to analyze the reasons States often fail to discharge their duty to protect against corporate abuse, and to spread awareness of the compelling need for global standards on business and human rights to strengthen the protection of human rights and provide a common framework to address business conduct (ESCR-NET, 2007).

In his 2008 report, "Protect, Respect and Remedy: A Framework for Business and Human Rights," the SRSG outlined a three-part conceptual framework: (i) States have the duty to protect against human rights abuses by third parties, including business, through appropriate policies, regulation and adjudication; (ii) companies have the responsibility to respect human rights, which the SRSG defined as in essence involving managing the risk of human rights harm with a view to avoiding it; and (iii) victims require greater access to effective remedies, including non-judicial grievance mechanisms (UNITED NATIONS, 2008b). This broad framework was welcomed by business associations, governments and many civil society groups, who appreciated the fact that it encapsulated many of the conclusions that expert bodies and human rights advocates had previously expressed.

\section{Emerging issues for debate within the SRSG mandate, 2009-2011}

In June 2008, the Human Rights Council extended the SRSG's mandate for another three years and requested him to "operationalize" the framework by providing concrete guidance and recommendations to States and business (UNITED NATIONS, 2008a). The SRSG has set out his priorities and has made clear that his final concrete recommendations will be made in 2011, at the end of his mandate (UNITED NATIONS, 2008c).

These recommendations have the potential to define UN approaches to corporate accountability issues for years to come. While much valuable corporate accountability work may best be pursued outside the scope of this mandate, the current environment opens a small, but important space for groups to identify and prioritize issues for deeper debate and further action, offer suggestions where they think the SRSG's work could lead to meaningful results, and offer critiques where they are concerned by the direction the SRSG may be taking (ESCR-NET, 2009).

\section{Future direction of the corporate accountability agenda in the UN}

Despite these potential openings, it is not clear after more than a decade of false starts and continuing debate, that the $\mathrm{UN}$ is any closer to developing appropriate, enforceable standards for business and human rights. In fact, the opportunity for reaching agreement on a soft law instrument of global standards for business and human rights may have been lost for the immediate future. After the near collapse 
of the global financial system, the emerging economies of China and India are, if anything, less hospitable now to persuasion than they were in 2004. It seems inevitable that ad hoc, voluntary alternatives will continue to be proposed as a means of filling the protection gap. This is already the case in relation to private military and security companies (PMSCs), which at first sight appears to be a startling omission from the work plan of the SRSG, given the public function they fulfil and their lack of accountability to international humanitarian and human rights law. According to the International Peace Institute,

In the absence of the necessary support (political and material) for the UN to become the primary forum for states to develop more detailed regulation, the most significant contemporary international efforts to improve standards implementation and enforcement within the global security industry are now occurring outside the UN (COCKAYNE et al, 2009, p. 53) 7 .

The SRSG's approach, which has been criticised by NGOs for being unduly conservative, can claim a number of achievements, not least, as noted by the High Commissioner for Human Rights, the affirmation by the Human Rights Council that 'transnational corporations and other business enterprises have a responsibility to respect human rights' (resolution 8/7). This sets "a new and clear benchmark and represents and important milestone in the evolving understanding of human rights in our societies." (PILLAY, 2009). OECD governments however remain cautious about the implications of the SRSG's analysis of the State duty to protect against human rights abuses by non-State actors under international law, even while they are expected to initiate a review of the OECD Guidelines for Multinational Enterprises in 2010. Industry bodies for their part, such as the International Council on Mining and Metals, have also enthusiastically responded to the SRSG's call for human rights impact assessments and company-level grievance mechanisms (INTERNATIONAL COUNCIL ON MINING AND METAL, 2008).

In his 2008 report, the SRSG referred to the incomplete and flawed "patchwork of mechanisms" which exists today to ensure that people and communities affected by business-related abuses have access to a remedy (UNITED NATIONS, 2008b, para. 87). In 2009, he further reiterated the State duty to "investigate, punish and redress" such abuses "within their territory and/or jurisdiction.” (UNITED NATIONS, 2009, para. 87). But unless governments demonstrate a greater willingness to use their powers to reassert their regulatory role, progress in the exercise of extra-territorial jurisdiction to end the impunity enjoyed by abusive private actors is unlikely. NGOs remain unconvinced that a requirement on companies to reduce the risk of complicity in human rights violations, particularly in conflict zones, by conducting enhanced due diligence will be truly effective. Such measures, as highlighted by the Global Witness v. Afrimex case (UNITED KINGDOM NATIONAL CONTACT POINT FOR THE OECD GUIDELINES FOR MULTINATIONAL ENTERPRISES, 2008), unless accompanied by a rigorous enforcement mechanism for non-compliance, may do little to alter company behaviour. 
It may be too soon to predict, but the SRSG's most tangible legacies may be his clarification of the issues through a Respect, Protect and Remedy framework, along with the second pillar of his framework. Professor Ruggie is developing a set of guiding principles on the corporate responsibility to respect and related accountability measures, which unlike with the Norms, the SRSG believes he has an explicit mandate from the Human Rights Council to elaborate (UNITED NATIONS, 2008c, para. 2). But in the absence of a major shift in the attitude and actions of governments towards effective regulation of companies at home and abroad, and without a clear international legal framework and enforcement mechanism, it is unclear how companies will be effectively brought to account if they should fail to meet their human rights responsibilities. At most, failure will 'subject companies to the courts of public opinion' (UNITED NATIONS, 2008c, para. 2). Some experts (JERBI, 2009) point to the fact that the SRSG has convened 'a global leadership group' to advise him, echoing the way in which Francis Deng, a former Special Representative, developed the highly acclaimed Guiding Principles on Internally Displaced Persons (IDPs). But Deng's first-hand knowledge of IDPs and the specific situations in countries such as Sudan and Colombia, which gave rise to mass displacement, imbued his work with a high degree of credibility. It is unclear whether a global leadership group can help the SRSG overcome the credibility gap arising from his lack of personal contact with individuals and communities affected by business-related abuse and direct knowledge of the circumstances in which they occur. Another concern for human rights advocates is that the SRSG defines company responsibility in terms of evolving social expectations, a weaker formulation than that used by other UN bodies, which have stated that this responsibility stems from the Universal Declaration on Human Rights and existing international law (ESCR-Net, 2009).

Ultimately the greatest achievement of the SRSG's six-year mandate may be judged to have been the fact that it has kept the business and human rights debate alive in the UN, and that in the process it helped stimulate a tremendous amount of new research and interest outside of the UN. But after the failure of the Norms, powerful arguments and demands remain for the creation of global standards on business and human rights, and effective mechanisms to ensure the human right to a remedy for individuals and communities suffering the consequences of business misconduct. These demands will only intensify in the years to come. 


\section{REFERENCES}

ALSTON, Philip. 1994. Human Rights in 1993: How Far has the United Nations Come and Where Should it Go From Here?. In: NOWAK, M. World Conference on Human Rights. Vienna: Ludwig Boltzmann Institute of Human Rights.

CLAPHAM, Andrew. 2006. Human Rights Obligations of Non-State Actors. Oxford: Oxford University Press.

COCKAYNE, James et al. 2009. Beyond Market Forces: Regulating the Global Security Industry. New York: International Peace Institute.

FEENEY, Patricia 1998. Accountable Aid: Local Participation in Major Projects. Oxford: Oxfam International Publications.

HANLON, Joseph (Ed.). 1990. Independent Expert Study Group on the Evaluation of the Application and Impact of Sanctions Against South Africa. South Africa: the Sanctions Report - Documents \& Statistics. London: Commonwealth Secretariat.

INTERNATIONAL COMMITTEE OF RED CROSS. 2008. The Montreux

Document. Available at: http://www.eda.admin.ch/psc. Last accessed on: 15 Sept. 2009.

INTERNATIONAL COMMISSION OF JURISTS (ICJ). 2008. Corporate

Complicity \& Legal Accountability, Volume 1. Geneva: International Commission of Jurists. Available at: http://www.icj.org/IMG/Volume_1.pdf. Last accessed on: 15 Sept. 2009.

INTERNATIONAL COUNCIL ON HUMAN RIGHTS. 2002. Beyond Voluntarism: human rights and the developing international legal obligations of companies. Available at : http://www.reliefweb.int/rw/lib.nsf/db900sid/ASIN-7DBQ7F/\$file/ ICHRP_Beyond\%20Voluntarism.pdf?openelement. Last accessed on: 15 Sept. 2009.

INTERNATIONAL COUNCIL ON MINING AND METALS (ICMM). 2008. Human Rights in the Mining and Metals Industry: Overview, Management Approach and Issues. Available at: http://www.icmm.com/page/8331/icmmwelcomes-ruggie-report. Last accessed on: 15 Sept. 2009.

INTERNATIONAL LABOUR OFFICE. 1977. Tripartite Declaration of Principles Concerning Multinational Enterprises and Social Policy. Available at: http://www. ilo.org/public/english/employment/multi/download/english.pdf. Last accessed on: 15 Sept. 2009.

INTERNATIONAL NETWORK FOR ECONOMIC, SOCIAL AND CULTURAL RIGHTS (ESCR-NET). 2005. UN Human Rights Norms for Briefing Kit. Available at: http://www.escr-net.org/usr_doc/Briefing_Kit.pdf. Last accessed on: 15 Sept. 2009.

2006. Joint NGO Letter in response to the interim report of the UN Special Representative on Human Rights and Business. Available at: http://www.escrnet.org/usr_doc/NGO_Endorsements_-_NGO_Joint_NGO_Response.pdf. Last accessed on: 15 Sept. 2009.

2007. Joint Open Letter to the UN Special Representative on Business and Human Rights. Available at http://www.escr-net.org/actions_more/actions_more_ show.htm?doc_id=548976. Last accessed on 15 Sept. 2009. 
. 2008. ESCR-NET Corporate Accountability Working Group. Collective Report on Business and Human Rights. Available at: http://www.escr-net.org/ actions_more/actions_more_show.htm?doc_id=6934868parent_id=431015. Last accessed on: 15 Sept. 2009.

. 2009. ESCR-NET Corporate Accountability Working Group. Advocacy Guide on Business and Human Rights in the United Nations Part 1: The Mandate of the Special Representative. Available at: http://www.escr-net.org/usr_doc/ESCRNet_ BHRGuideI_Updated_Oct2009_eng_FINAL.pdf. Last accessed on: 26 January 2010.

JERBI, S. 2009. Business and Human Rights at the UN: What Might Happen Next?. Human Rights Quarterly, v. 31, n. 2, p. 299-320.

KINLEY, D.; CHAMBERS, R. 2006. The UN Human Rights Norms for Corporations: The Private Implications of Public International Law. Human Rights Law Review, v. 6, n. 3 .

PILLAY, N. 2009. Opening Statement: OHCHR Consultation on Business and Human Rights. Geneva, 5-6 Oct. Available at: http://www.business-humanrights. org/Documents/Navanethem-Pillay-speech-to-Geneva-consultation-Oct-2009.doc. Last accessed on: 15 Sept. 2009.

RICH, Bruce. 1995. Mortgaging the Earth: The World Bank, Environmental Impoverishment and the Crisis of Development. Boston: Beacon Press.

SALZMAN, J. 2005. Decentralized Administrative Law in the Organization for Economic Cooperation and Development. Law and Contemporary Problems, v. 68, n. $3 \& 4$, p. 189. Available at:

http://www.law.duke.edu/shell/cite.pl?68+Law+\&+Contemp.+Probs.+189+(summeraut umn+2005)\#H2N1. Last accessed on: 15 Sept. 2009.

TEITELBAUM, A. 2007. United Nations and Transnational Corporations: a deadly association. 4 Apr. Available at: http://thirdworldtraveler.com/United_Nations/ UN_TNCs_DeadlyAssoc.html. Last accessed on: 15 Sept. 2009.

UNITED KINGDOM NATIONAL CONTACT POINT FOR THE OECD GUIDELINES FOR MULTINATIONAL ENTERPRISES (UK NCP). 2008. Final Statement by the UK NCP for the OECD Guidelines for Multinational Enterprises: AFRIMEX (UK) LTD. 28 Aug. Available at: <http://www.oecd.org/ dataoecd/40/29/43750590.pdf>. Last accessed on: 15 Sept. 2009.

UNITED NATIONS ORGANIZATION. 1983. Comission on Transnational Corporations. Draft United Nations Code of Conduct on Transnational Corporations. Available at: <http://www.unctad.org/sections/dite/iia/docs/ Compendium//en/13\%20volume\%201.pdf>. Last accessed on: 15 Sept 2009.

1992. Rio Declaration on Environment and Development: The United Nations Conference on Environment and Development, Rio de Janeiro, Brazil 3-14 Jun. Available at: <http://www.unep.org/Documents.Multilingual/Default.asp?Documen $\mathrm{tID}=78 \&$ ArticleID=1163> Last accessed on: 26 January 2010.

1993. Vienna Declaration and Programme of Action : The World Conference Human Rights, Vienna, Austria 14-25 Jun. Available at: http://www2.ohchr.org/ english/law/vienna.htm. Last accessed on: 26 January 2010 
Conference on Women: Action for Equality, Development and Peace Beijing, 4-15 Sept. Available at: http://www.un-documents.net/beijingd.htm. Last accessed on: 26 January 2010

2003. Comission on Human Rights. Norms on the responsibilities of transnational corporations and other business enterprises with regard to human rights. U.N. Doc. E/CN.4/Sub.2/2003/12/Rev.2, 26 Aug. Available at: http://www. unhchr.ch/huridocda/huridoca.nsf/ (Symbol)/E.CN.4.Sub.2.2003.12.Rev.2.En. Last accessed on: 15 Sept. 2009.

2004. Comission on Human Rights. Responsibilities of transnational corporations and related business enterprises with regard to human rights. U.N. Doc. E/CN.4/DEC/2004/116. Available at: <http://ap.ohchr.org/documents/E/ CHR/decisions/E-CN_4-DEC-2004-116.doc>. Last accessed on: 15 Sept. 2009.

2005a. Comission on Human Rights. Human rights and transnational corporations and other business enterprises. U.N. Doc. E/CN.4/RES/2005/69. 20 Apr. Available at <http://ap.ohchr.org/documents/E/CHR/resolutions/E-CN_4RES-2005-69.doc>. Last accessed on: 15 Sept. 2009.

. 2005b. Comission on Human Rights. Report of the United Nations High Commissioner on Human Rights on the responsibilities of transnational corporations and related business enterprises with regard to human rights. U.N. Doc. E/CN.4/2005/91. 15 Feb. Available at: http://econsense.org/_CSR_INFO_ POOL/_INT_VEREINBARUNGEN/images/2005\%20REPORT\%20OF\%20 THE\%20SUB-COMMISSION\%20ON\%20THE\%20PROMOTION.pdf. Last accessed on: 15 Sept. 2009.

2006. Comission on Human Rights. Interim report of the Special Representative of the Secretary-General on the issue of human rights and transnational corporations and other business enterprises. U.N. Doc. E/ CN.4/2006/97. Available at: <http://daccess-dds-ny.un.org/doc/UNDOC/GEN/ G06/110/27/PDF/G0611027.pdf?OpenElement>. Last accessed on: 15 Sept. 2009.

. 2007a. Human Rights Council. Business and Human Rights: Mapping International Standards of Responsibility and Accountability for Corporate Acts. U.N. Doc. A/HRC/4/035. Available at: <http://www.business-humanrights.org/ Documents/SRSG-report-Human-Rights-Council-19-Feb-2007.pdf $>$. Last accessed on: 15 Sept. 2009.

2007b. United Nations Conference on Trade and Development (UNCTAD).

World Investment Report: Transnational Corporations, Extractive Industries and Development. Geneva. Available at: <http://www.unctad.org/en/docs/wir2007_ en.pdf $>$. Last accessed on: 15 Sept. 2009.

2008a. Human Rights Council. Mandate on the Special Representative of the Secretary-General on the issue of human rights and transnational corporations and other business enterprises. UNHRC Resolution 8/7, 18 Jun.

. 2008b. Human Rights Council. Protect, Respect and Remedy: A Framework for Business and Human Rights, Report of the Special Representative of the Secretary-General on the issue of human rights and transnational corporations and other business enterprises, John Ruggie. U.N. Doc. A/HRC/8/5. 7 Apr. Available at: <http://www.reports-and-materials.org/Ruggie-report-7-Apr-2008. pdf>. Last access on: 15 Sept. 2009. 
.2008c. Preliminary Work Plan: Mandate of the Special Representative on the Issue of Human Rights and Transnational Corporations and other Business Enterprises. 10 Oct. Available at: http://www.reports-and-materials.org/Ruggiepreliminary-work-plan-2008-2011.pdf. Last accessed on: 15 Sept. 2009.

. 2008d. UN Global Compact. Available at: http://www.unglobalcompact.org/. Last accessed on: 15 Sept. 2009.

. 2009. Business and human rights: Towards operationalizing the "protect, respect and remedy" framework, Report of the Special Representative of the Secretary-General on the issue of human rights and transnational corporations and other business enterprises. U.N. Doc. A/HRC/11/13. 22 Apr. Available at: <http:// www2.ohchr.org/english/bodies/hrcouncil/docs/11session/A.HRC.11.13.pdf>. Last accessed on: 15 Sept. 2009.

UNITED STATES OF AMERICA. 1975. United States Senate. Church Report: Covert Action in Chile 1963-1973. Available at: http://foia.state.gov/Reports/ChurchReport. asp\#B.\%20Executive\%20Command\%20and\%20Control\%20of\%20Major\%20 Covert\%20Action. Last accessed on: 15 Sept. 2009.

\section{NOTES}

1. While the UN Code of Conduct was never intended to be a human rights instrument per se, it did make clear reference to the responsibility of business to respect human rights in para. 13: "Transnational corporations should/shall respect human rights and fundamental freedoms in the countries in which they operate. In their social and industrial relations, transnational corporations should/shall not discriminate on the basis of race, colour, sex, religion, language, social, national and ethnic origin or political or other opinion. Transnational corporations should/shall conform to government policies designed to extend equality of opportunity and treatment."

2. One of the reasons the Code of Conduct for TNCs was unpalatable to Northern governments was that newly independent developing countries conceived of it as part of 'a New International Economic Order'.

3. Many of the provisions of the ILO Tripartite Declaration of Principles Concerning Multinational Enterprises and Social Policy were incorporated into the revised versions of the OECD Guidelines for Multinational Enterprises.

4. The Declaration on Violence against Women (adopted by the UN General Assembly in 1993), for example, called on States to punish acts of violence against women, whether those acts are perpetrated by the State or by private persons.

5. Now the Berthold Beitz Professor in Human Rights and International Affairs, John F. Kennedy School of Government, Harvard University; Affiliated Professor in International Legal Studies, Harvard Law School; former Assistant Secretary-General and senior advisor for strategic planning to SecretaryGeneral Kofi Annan.

6. The SRSG's initial two-year mandate, later extended to three, was to clarify the implications for transnational corporations and other business enterprises the concepts of 'complicity' and 'spheres of influence'.

7. Swiss Government together with the International Committee of the Red Cross has adopted The Montreux Document on private military and security companies (PMSCs), which has been endorsed by over 30 governments. It seeks to promote respect for international humanitarian law and human rights by PMSCs in armed conflicts. The document is available at: http://www.eda.admin.ch/psc. The Swiss Government has also taken a lead in developing a Code of Conduct for Private Military and Security Companies, which overlaps with the SRSG's mandate. 


\section{RESUMOS}

Nos últimos 40 anos, as Naçôes Unidas têm buscado elaborar parâmetros globais para responsabilizar empresas pelo envolvimento com violaçôes de direitos humanos. Este artigo detalha a atenção cada vez mais dispensada às violaçôes de direitos que envolvam empresas, bem como analisa as limitaçóes apresentadas por uma abordagem centrada nos Estados no que diz respeito a regular empresas num mundo globalizado. $\mathrm{O}$ artigo investiga as razóes para que o Projeto das Naçóes Unidas de Normas sobre Responsabilidades das Empresas Transnacionais não tenha se consumado, bem como pondera os pontos positivos e negativos da 'Estrutura Proteger, Remediar e Respeitar', adotada pelo Conselho de Direitos Humanos das Naçôes Unidas em 2008. O artigo conclui com a seguinte advertência: ao menos que sejam atendidas as demandas em prol de parâmetros globais e instrumentos efetivos para vítimas de práticas empresariais nocivas, a pressão por mudança só tende a aumentar.

\section{PALAVRAS-CHAVE}

Empresas e direitos humanos - Normas da ONU - Responsabilidade das empresas.

\section{RESUMEN}

Durante los últimos 40 años, la Organización de Naciones Unidas ha llevado a cabo varios intentos de elaborar estándares globales que permitan hacer responsables a las empresas por su participación en violaciones de derechos humanos. Este artículo describe la creciente toma de conciencia sobre las violaciones de derechos humanos vinculadas a las empresas y las limitaciones que ofrece el enfoque tradicional centrado en el Estado, al momento de regular la conducta de las empresas en la era de la globalización. Reflexiona sobre las razones del decaimiento del Proyecto de Normas de la ONU sobre Responsabilidades de las Empresas Trasnacionales, y evalúa las fortalezas y debilidades del Marco "Proteger, Respetar y Remediar" adoptado por el Consejo de Derechos Humanos el ańo 2008. El artículo concluye con la advertencia de que a menos que sean atendidas las demandas por estándares globales y por un recurso efectivo para los afectados por malas prácticas empresariales, lo único seguro es que se intensificará la presión para un cambio.

\section{PALABRAS CLAVE}

Empresas y derechos humanos - Normas de Naciones Unidas - Responsabilidad/ Accountability de las empresas. 